\title{
О.А. Ганжа
}

\section{УМОВИ РОЗСИПОУТВОРЕННЯ ТЕРИТОРІЇ КРАСНОКУТСЬКОГО РОДОВИЩА}

На основі палеореконструкцій середньоновопетрівського етапу розвитку Субпаратетісу визначено основні умови розсипоутворення для Харківсько-Сумської розсипної зони - тектонічні, гідродинамічні, геоморфологічні і структурно-седиментаційні. Запропоновано локальну схему розсипоутворення для площі Краснокутського родовища, яка ґрунтується на концепції постачання розсипоутворювального матеріалу (РУМ) переважно річковою артерією з утворенням області розсипоутворення в безпосередньому наближенні до дельти в межах двох фаціальних зон - прибережного мілководдя і морського мілководдя. Враховується також надходження РУМ унаслідок латерального руху вздовжбереговими течіями й перемивання підстильних і латерально прилеглих товщ. На основі представленого механізму розсипоутворення розроблено критерії прогнозування розсипів у зональному масштабі: стратиграфічний (приурочення розсипів до середньоновопетрівської підсвіти), фаціальний (виділення двох розсиповміщувальних зон 3 відповідними характеристиками зруденіння), гідродинамічний, літофаціальний, палеотранспортний, палеогеоморфологічний і етапноседиментаційний (зв'язок із секвенсними циклами еволюції басейну з відповідними умовами седиментації).

Ключові слова: умови розсипоутворення, Краснокутське родовище, титано-цирконієві розсипи, середньоновопетрівська підсвіта, міоцен.

Вступ. У Загальнодержавній програмі розвитку мінерально-сировинної бази України на період до 2030 року руди титану й цирконію належать до стратегічних видів мінеральної сировини. Розсипні родовища, які становлять істотну частину сировинної бази цих руд, поступово вичерпуються, нові - майже не розвідуються. Тому виникає потреба детального вивчення механізму розсипоутворення розвіданих родовищ для формування критеріїв прогнозування ресурсів у зональному масштабі.

Mета публікації - висвітлення результатів дослідження умов розсипоутворення на площі Краснокутського родовища з відображенням методології та методів дослідження; побудовою регіонально-зональної схеми розсипутворення й представлення локальної схеми розсипоутворення на площі родовища.

Краснокутське родовище титано-цирконієвих руд простягається на північно-східному схилі Дніпровсько-Донецької западини (ДДЗ) і належить до Краснокутського розсипного поля Харківського розсипного району Харківсько-Сумської розсипної зони. Родовище відкрите 1957 року, попередню розвідку із затвердженням запасів НТР тресту "Київгеологія" здійснено 1961 року. Родовище за загальною структурою являє собою однопластовий розсип, що охоплює чотири рудні поклади - Степанівський, Центральний, Південний та Козіївський. Рудні асоціації досить різноманітні і містять ільменіт, рутил, циркон, лейкоксен, монацит, дистен, силіманіт, ставроліт та ін. Розсип приурочений до відкладів новопетрівської світи.

Сучасний стан проблеми, методологія та методи. Найвагоміший внесок у вивчення титано-цирконієвих розсипів північно-східного схилу ДДЗ здійснив ще в 60-70-ті роки XX ст. І.С. Романов. У той період активно проводилися пошуково-рекогносцирувальні роботи на титано-цирконієві руди по всій території України і на території Харківсько-Сумської розсипної зони зокрема. Було проведено попередню розвідку Краснокутського родовища, унаслідок чого підраховано запаси по категорії $\mathrm{C}_{1}$ та $\mathrm{C}_{2}$. Опубліковано низку наукових праць [10, 11], в яких висвітлено основні ознаки геологічної будови, особливості літологофаціального та мінерального складу, умови формування розсипів тощо.

У 1961-1963 рр. на території досліджуваного району виконувалися пошукові та рекогносцирувальні роботи Харківсько-Сумської розсипної зони на титано-цирконієві розсипи під керівництвом В.Г. Довбенко. Унаслідок цих робіт були виявлені Артемівський, Пісочинський, Верхньо-Бишкінський та Гайдарівський розсипи.

(с) О.А. Ганжа, 2017 
Цілеспрямовані пошуки циркон-ільменітових розсипів розпочалися з геологічними зйомками масштабу 1:50 000. У 1973-1993рр. внаслідок проведення геологічної зйомки О.П. Шапіро, Д.В. Зайченко, В.М. Колесников, А.Г. Денисюк виявили велику кількість проявів розсипів.

У 1990-1993 рр. виконано пошуково-оцінювальні роботи Богодухівської та НовоВодолазької площ для визначення розмірів відомих розсипів у долині р. Мерчик (Шванюк О.П., 1993).

Інтенсивний розвиток сучасних методів і технологій інформаційного забезпечення всіх заходів геологічної діяльності та сучасні стратиграфічні схеми слугували основою для аналізу, доповнення та переінтерпретації наявних поглядів на проблему розсипоутворення північно-східного схилу ДДЗ.

Упродовж останніх років науково-технічний колектив (з участю автора) активно досліджував проблему фрормування й прогнозування титано-цирконієвих розсипів новопетрівської світи ДДЗ та прилеглих територій. Проведено неодноразові польові дослідження, зібрано чималий обсяг фрактичного матеріалу, виконано лабораторні дослідження піщаної товщі, що дало змогу здійснити суттєву переінтерпретацію наявних даних. Унаслідок цього створено схему літостратиграфрічного розчленування новопетрівської світи північно-східного схилу ДДЗ (за основу якої прийнято Проект модернізованих стратиграфрічних схем (Зосимович В.Ю.)), проведено палеогеографічні реконструкції басейну Субпаратетісу (території Української розсипної субпровінції) i великомасштабний фаціальний аналіз, розроблено цифрову структурно-літологічну модель Краснокутського родовища [1, 2, 3, 4, 6, 12, 13]. На основі цих досліджень розроблено схему розсипоутворення на площі Краснокутського родовища титаноцирконієвих руд.

Зазначена схема розсипоутворення створена на основі зіставлення отриманих конкретних даних 3 палеогеографії, літофаціального складу, палеофаціальних характеристик, палеогідродинаміки, седиментаційних та інших умов Субпаратетісу (як басейну розсипоутворення) середньоновопетрівської підсвіти (як розсиповміщувальної) і безпосередньо площі самого родовища, що узгоджена із сучасною теоретичною схемою розсипоутворення комплексних прибережно-морських розсипів рідкіснометалевотитанової спеціалізації [6].

Регіонально-зональна схема розсипоутворення. Площа родовища належить до Харківського розсипного району Харківсько-Сумської розсипної зони. Для цього району (можливо - всієї зони) встановлюються гіпотетичні розсипоутворювальні фоормації певних масивів метаморфічних утворень Воронезького щита (віком 2140 - 1930 млн років) 3 їхніми корами вивітрювання [10, 11, 14]. Первинне палеотранспортування РУМ після дії схилових процесів і перенесення тимчасовими потоками здійснювалося палеорічковими артеріями на досить широких водозборах схилу Воронезького щита і краєвої зони ДДЗ. Частково цей матеріал перевідкладався в морських басейнах крейдового і палеогенового часу. Утворення проміжних колекторів РУМ відбувалося переривчасто, з формуванням як континентальних, так і морських відкладів, що вміщують важкі мінерали.

Основні етапи формування проміжних колекторів РУМ: ранньокрейдовий, пізньокрейдовий (особливо - сеноманський), палеогеновий (зі стадіями: канівськобучацькою, особливо інтенсивною - межигірською, мало інтенсивною - київською).

Середньоновопетрівський етап еволюції Субпаратетісу був сприятливим для поєднання низки обов'язкових умов, потрібних для розсипоутворення - тектонічних, гідродинамічних, геоморфологічних, гідрологічних і локально - структурноседиментаційних. Розглянемо за порядком.

3 початку середньоновопетрівського часу протилежно спрямовані неотектонічні рухи - висхідні в областях розміщення розсипоутворювальних фрормацій (Воронезький та Український щит) і частково проміжних колекторів, та низхідні в межах седиментаційного «морського» басейну (Субпаратетісу) - забезпечили, по-перше, утворення самого 
басейну із системою рік, що в нього впадали (геоморфологічні і гідродинамічні умови), а по-друге, - дію механізму переміщення мас РУМ до цього басейну.

Гідрологічний режим басейну - режим трансгресій-регресії - потребує на особливий розгляд. За умов звичайних морських басейнів він спричинений двома чинниками: регіональною тектонічною динамікою й евстатичними коливаннями. Для нашого випадку дія евстатичних коливань, як глобального явища, незначна. Згідно з природою Субпаратетісу механізм змін рівня басейну зумовлювався об'ємом надходження річкових вод (включно з кліматичними умовами), причому седиментаційні аспекти цих коливань збігаються 3 такими звичайних трансгресій-регресій (за винятком певних геохімічних характеристик).

Гідродинамічні умови басейну за розміром і конфрігурацією забезпечили дію двох визначальних чинників розсипоутворення: вздовжберегових течій і хвильових рухів. Кругові течії в такому видовженому порівняно вузькому басейні були незначними.

Структурно-седиментаційні умови в середньоновопетрівському басейні проявлялись у двох головних генетичних формах: успадкованих і конседиментаційних. Успадковані були спричинені наявністю певних структурних виступів і виражались у вигляді вигинів берегової лінії, що утворювали більш-менш відкриті затоки (наприклад, площі Краснокутського родовища, Самотканської групи родовищ тощо) (рис. 1).

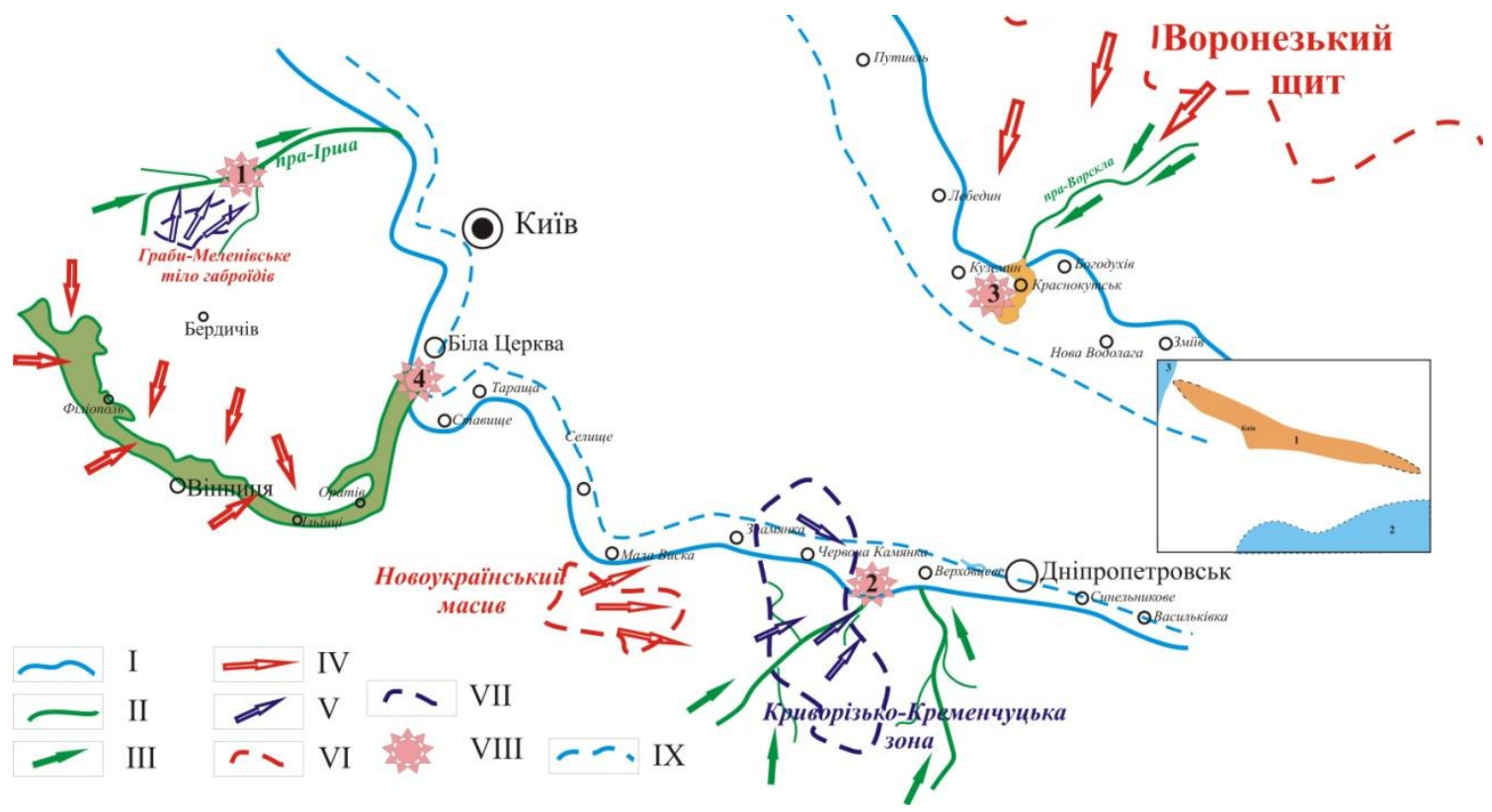

Рис. 1. Палеогеографічна схема Субпаратетісу етапу формування середньоновопетрівської підсвіти. I - берегова лінія

Субпаратетісу; II - палеоріки; III - напрямок знесення рудоутворювального матеріалу палеоріками; IV - напрямок знесення титанових і цирконієвих мінералів; V - напрямок знесення титанових мінералів; VI - області знесення титанових і цирконієвих мінералів; VII - області знесення титанових мінералів; VIII - родовища (1 - Злобицьке, 2 - Самотканська група, 3 - Краснокутське, 4 - Тарасівське); IX - межа зони морського і прибережного мілководдя. Врізка: 1 - Субпаратетіс; 2 - Тетіс; 3 - Атлантика [13]

Такі вигини зумовлювали оптимальні гідродинамічні умови для розсипоутворення, що могли реалізуватись у разі забезпечення постачання достатніх об'ємів рудного матеріалу. Консидементаційні фрорми - акумулятивні та ерозійні - утворювали групу седиментаційних пасток.

Механізм розсипоутворення на площі Краснокутського родовища. Побудова схеми розсипоутворення на площі Краснокутського родовища ґрунтується на принциповому положенні про те, що основним джерелом постачання РУМ для цієї площі 
були річки. Передбачається також надходження РУМ унаслідок латерального руху вздовжбереговими течіями, перемивання підстильних та латерально прилеглих товщ. Докази такої схеми: встановлення дельтових відкладів у розрізі середньоновопетрівської підсвіти; розподіл літофацій і фацій у розрізі й за латераллю, що відображає просторову послідовність (зональність) літофаціальних і фаціальних комплексів (від дельтових до мілководно-морських); розподіл зруденіння, що відображає просторову міграцію смуг максимальних концентрацій у часі.

Дельтові фрації представлені типовими літонаборами чергування проверстків пісків дрібно- і тонкозернистих («фонових»), середньо- і крупнозернистих, зрідка - гравелітів і глин. Для пісків характерна коса, різноспрямована, клиноподібна верствуватість, яка виражена зміною гранулометричного складу (рис. 2), наявністю темнозабарвленого органічного або глинистого матеріалу тощо. Концентрації рудного матеріалу в дельтових відкладах незначні, оскільки він зносився в розсіяній фрормі.
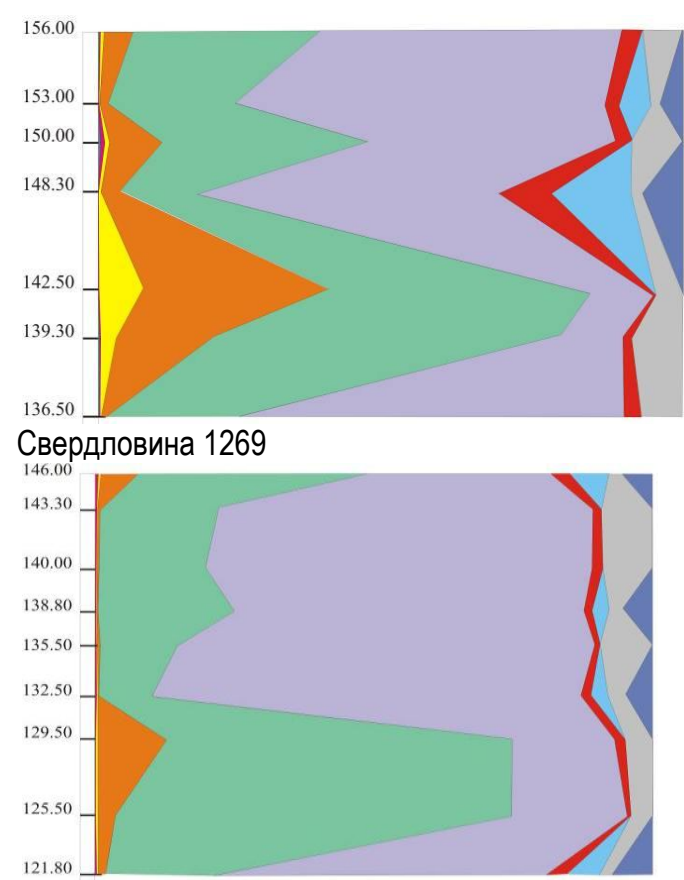

Свердловина 1298

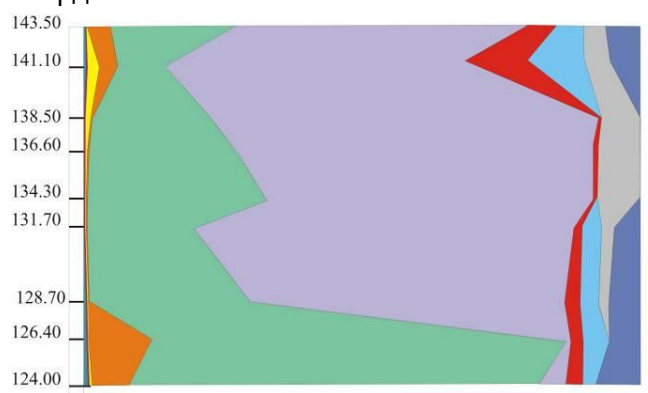

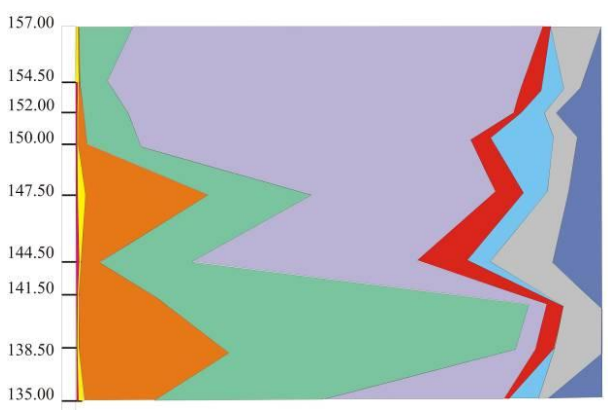

Свердловина 1285

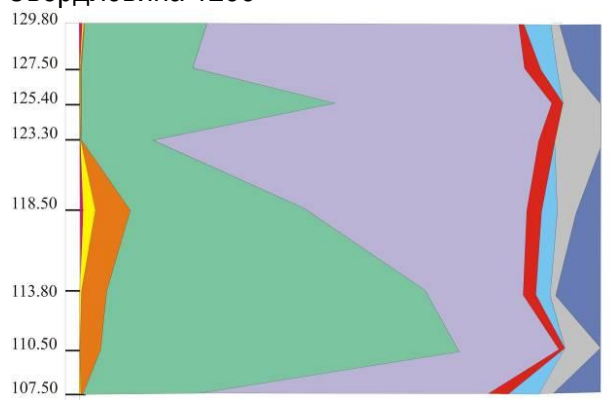

Свердловина 1315

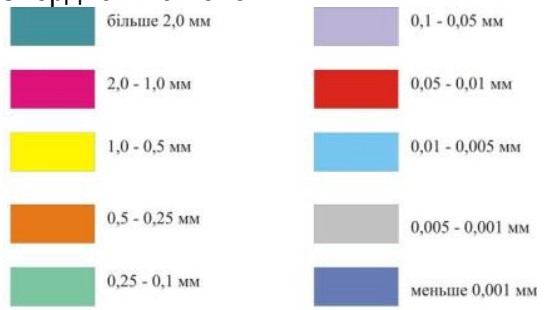

Свердловина 1262

Рис. 2. Гранулометрична характеристика розрізів бурових свердловин площі Краснокутського родовища (графіки побудовані на основі результатів гранулометричного аналізу Сумської геологорозвідувальної партії №17 1957 р.)

Вказані відклади локалізуються в нижній частині середньоновопетрівської підсвіти і утворюють лінзоподібні і пластово-лінзоподібні форми ярусного розміщення. 
На основі визначення просторового розподілу фраціальних типів (за інтерпретацією модельних візуалізацій літофрацій і гранулометричного складу) побудовано схему площового розподілу переважальних фаціальних типів на площі Краснокутського родовища (рис. 3). На цій схемі показано три зони поширення переважальних басейнових фацій: морського мілководдя (у південно-західному секторі площі), прибережного мілководдя (літоралі), що утворює смугу південно-східного простягання 3 криволінійною північно-східною границею, і дельти, що утворює в плані пляму ускладненої форми, видовжену в субмеридіальному напрямку, тобто субперпендикулярну береговій лінії. Остання зона перетинає зовнішню частину смуги розвитку фрацій прибережного мілководдя (що є ознакою річкових винесень).

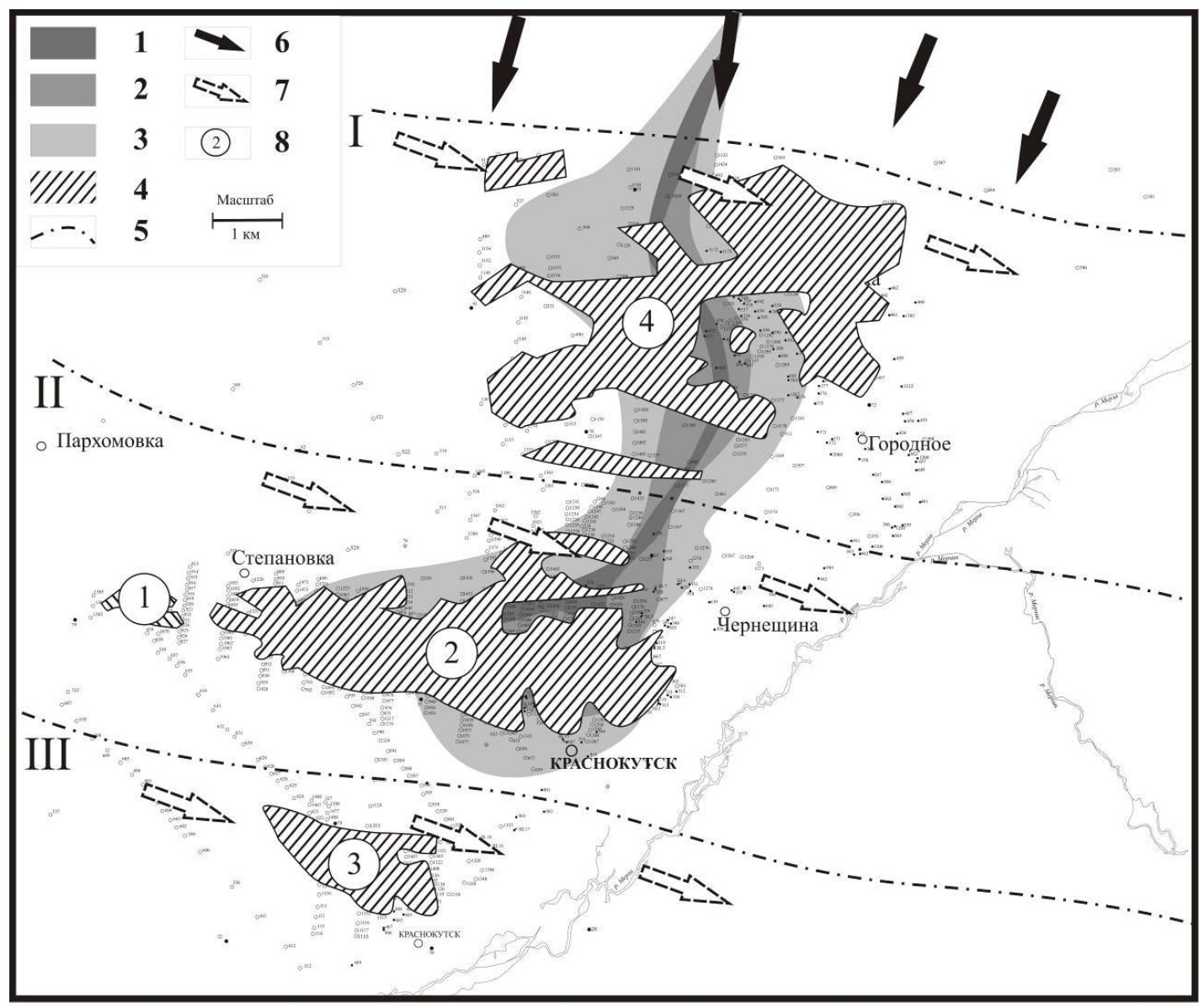

Рис. 3. Палеогеографічна схема етапу формування середньоновопетрівської підсвіти полтавської серії (ранній середній міоцен) Краснокутського титано-цирконієвого родовища

1-3 - дельта (1 - пісок середньо- та крупнозернистий, 2 - пісок різнозернистий (дрібно- та середньозернистий), 3 - глина); 4 контури рудних покладів; 5 - положення рівня стояння басейну; 6 - напрямок надходження рудного матеріалу; 7 - напрямок руху вздовжберегових течій; 8 - рудні поклади (1 - Степанівський, 2 - Центральний, 3 - Південний, 4 - Козієвський)

Згідно із запропонованим положенням загальна генетична схема об'єкта має відобразити два аспекти: систему просторової зональності на певний момент часу й еволюцію цієї системи в просторі за часом.

Система просторової зональності охоплює два функціональні елементи: джерело надходження РУМ (рис. 4) і область його сепарації (з двома фраціальними зонами: прибережного мілководдя і морського мілководдя). 


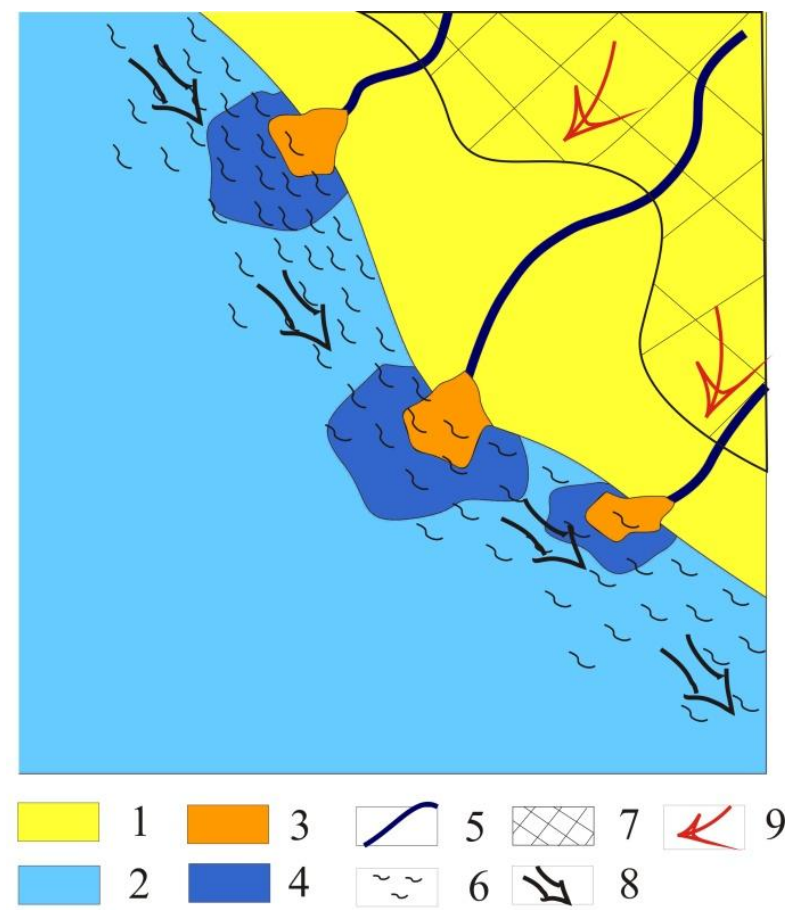

Рис. 4. Принципова схема динамічної системи розсипоутворення «надходження - сепарація - садження» рудоутворювального матеріалу для умов північно-східного узбережжя Субпаратетісу

1 - суходіл, 2 - кінцевий басейн, 3 - дельти, 4 - зона сепарації РУМ, 5 - палеоріки, 6 - хвилеприбійна діяльність басейну; 7 - джерела постачання РУМ; 8 - напрям руху вздовжберегових течій; 9 - напрям надходження рудного матеріалу

Рудна характеристика цих елементів така. Для області сепарації вона збігається із загальновизнаними теоретичними уявленнями: у зоні морського мілководдя - розсіяна, рівномірна, у зоні прибережного мілководдя - нерівномірна, 3 максимальними концентраціями і запасами, зокрема промисловими. У відкладах дельти рудна мінералізація незначна, розсіяна, більш-менш рівномірна.

Еволюція цієї системи зміщення просторової зональності в часі пов'язана 3 переходом від трансгресивного до регресивного ритмів середньоновопетрівського седиментаційного циклу й виражена в поступальній міграції з півночі на південь (унаслідок переносення РУМ вздовжбереговими течіями), і 3 нижніх горизонтів середньоновопетрівської підсвіти до середніх і верхніх (унаслідок перемивання підстильної товщі).

Наслідком цієї міграції $€$ утворення трьох розсипних смуг на площі родовища північної (Козіївський поклад), центральної (Центральний і Степанівський поклади) i південної (Південний поклад). Ці смуги відповідають трьом етапам тимчасової стабілізації берегової лінії басейну з відповідними фаціальними зонами розсипоутворення. Найбільш «продуктивним» був середній етап, що характеризується максимальними концентраціями рудного матеріалу і його питомими запасами.

Механізм сепарації важких мінералів відповідав такому для розсипів прибережноморського геолого-генетичного типу (зважаючи на особливості, що притаманні зонам літоралі і субліторалі), що підтверджується характеристиками структурно-текстурних ознак рудоносних піщаних порід. Це пов'язано з тим, що гідродинаміка Субпаратетісу на етапі розсипоутворення майже повністю відповідала умовам звичайних морських басейнів. Потрібно зазначити приуроченість смуг рудних тіл до флексуроподібних прогинів у рельєфі підошви середньоновопетрівської підсвіти. Генезис цих уступоподібних перегинів (успадкований чи консидементаційний) не встановлений, але в будь-якому разі лінії 
їхнього простягання збігаються зі смугами максимальних зосереджень важких мінералів на межі зон літоралі з фрацією надводного пляжу [6, 9, 15].

Це дає змогу пояснити фракт повної відповідності наведеної фрактичної схеми просторового (по площі і в розрізі родовища) розподілу рудного матеріалу теоретичній схемі розсипоутворення під час регресії басейну (рис. 5). Ця схема являє собою основу одного 3 аспектів структурно-седиментаційного критерію крупномасштабного прогнозування розсипів.

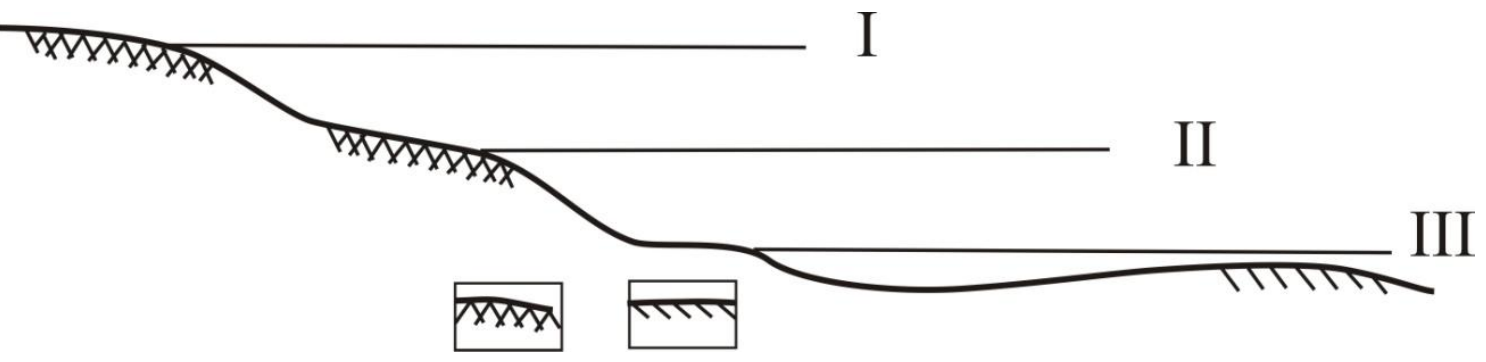

Рис. 5. Схема утворення серії розсипних тіл в умовах регресії басейну

I, II, III - послідовні рівні стояння басейну. 1 - розсипи літоралі; 2 - розсипи мілководдя [6]

Основні геолого-промислові характеристики розсипів - загальний об'єм рудних ресурсів і насиченість рудних тіл - визначалися такими чинниками. Загальний об'єм ресурсів зумовлений об'ємом рудного матеріалу, що надходив до басейну розсипоутворення. Ступінь насиченості рудних тіл (концентрації важких мінералів) контролювався локальними гідродинамічними і структурно-седиментаційними умовами.

Отже, обмеженість загального об'єму ресурсів на площі родовища (порівнюючи із Самотканською групою розсипів) визначалася двома умовами: обмеженістю об'ємів рудного матеріалу, що надходив живлющою річковою артерією, і незначною роллю постачання РУМ вздовжбереговими течіями. Порівняно низький рівень рудної насиченості зумовлювався, по-перше, чинником обмеженості об'ємів рудного матеріалу, а по-друге, недостатністю седиментаційних пасток нижчого рангу.

Критерії прогнозування перспективних площ. За нашим визначенням Харківський розсипний район являє собою кінцеву частину теригенно-седиментаційної провінції, для якої визначений типовий об'єкт локальної масштабності (площа Краснокутського родовища), мінералогічні особливості, розсипоутворювальні формації і джерела постачання РУМ, схеми палеотранспортування й механізм розсипоутворення.

Схема розсипоутворення в кінцевому басейні (Краснокутське родовище) дала змогу з'ясувати додаткові критерії прогнозування розсипів зональної масштабності. Нагадуємо, що комплекс критеріїв регіональної масштабності охоплює: стратиграфічний (приурочення розсипів до середньоновопетрівської підсвіти), фаціальний (виділення двох розсиповміщувальних зон з відповідними характеристиками зруденіння), гідродинамічний. Цей комплекс критеріїв $€$ дієвим і для зонального прогнозування. Додатковими критеріями $\epsilon$ : палеофаціальний, літофраціальний, палеотранспортний, палеогеоморфологічний i етапно-седиментаційний.

Різномасштабні палеофаціальні критерії ґрунтуються на принциповій схемі розсипоутворення: «надходження - сепарація - осадження РУМ», яку ми розробили для умов північно-східного узбережжя (рис. 4). В основу цієї схеми покладена загальновизнана аксіоматична ідея, що основним джерелом надходження рудного матеріалу до басейну розсипоутворення прибережно-морського типу $\epsilon$ річкові артерії (М.О. Шило, Н.Г. ПатикКара $[9,15]$ та ін.) (не враховуючи зон абразійних розсипів). Розсипна реалізація річкових потоків РУМ відбувається у двох фраціальних і гідродинамічних зонах басейнової сепарації - літоралі і субліторалі. Таким чином, як розсипоутворювальний треба розглядати фаціальний парагенез: дельта - зона прибережного мілководдя - зона морського мілководдя. Зважаючи, що суттєві концентрації важких мінералів для субліторалі в 
нашому випадку достовірно не встановлені, спрощуємо склад перспективного фраціального комплексу до послідовного ряду дельта - літораль.

Визначення палеотранспортування РУМ $€$ важливим допоміжним засобом прогнозування дельт, оскільки в умовах ДДЗ діагностування дельт (принаймні неогенового віку) має певні труднощі. Для вирішення цієї задачі основним методом $\epsilon$ геоморфологічний, який забезпечує досить достовірне визначення палеодолин. На прилеглих до ДДЗ територіях Воронезького щита проводилися відповідні дослідження (В.П. Палієнко), але вони не були завершені. Методика реконструкції палеодолин відпрацьована (В.П. Палієнко, О.О. Комлєв та ін. [5, 7, 8]). Прогнозування ділянок входження річкових витоків у кінцевий басейн седиментації дає основу для встановлення зон сепарації важких мінералів згідно з наведеною схемою.

Етапно-седиментаційний критерій передбачає фрункціонування в кінцевому басейні седиментації декількох етапів розсипоутворення. На площі Краснокутського родовища в перебігу еволюції седиментаційного басейну мали місце не менше трьох етапів розсипоутворення, що відповідає певним регресивним ритмам. Таким чином, при виявленні однієї смуги рудних покладів субпаралельної берегової лінії, можна прогнозувати наявність інших рудних смуг з просторовим розміщенням відповідно до наведеної вище схеми міграції фацій. Цей критерій є дієвим для умов усієї ХарківськоСумської розсипної зони.

Висновок. З'ясовано механізм розсипоутворення на площі Краснокутського родовища та встановлено, що основним джерелом постачання РУМ для цієї площі були річкові артерії, підлегле значення надходження РУМ мав латеральний рух уздовжберегових течій та перемивання підстильних і латерально прилеглих товщ.

Установлений механізм розсипоутворення, на нашу думку, є дієвим для умов північно-східного узбережжя Субпаратетісу, принаймні в межах Харківського розсипного району. Виокремлено критерії прогнозування розсипів у зональному масштабі: стратиграфічний, фраціальний, гідродинамічний, палеофаціальний, літофаціальний, палеотранспортний, палеогеоморфологічний і етапно-седиментаційний, які становлять основу для зонального прогнозування титано-цирконієвих розсипів Харківсько-Сумської розсипної зони.

\section{СПИСОК ЛІТЕРАТУРИ}

1. Зосимович В.Ю. О полтавской свите по Правобережью Среднего Днепра / В.Ю. Зосимович // Сб. науч. работ НИС КГУ. 1963. № 1. С. 3-7.

2. Зосимович В.Ю. Некоторые вопросы номенклатуры полтавских отложений / В.Ю. Зосимович, Э.Б. Савронь // Геол. журн. 1978. Т. 38, № 6 (183). С. 140-142.

3. Зосимович В.Ю. Событийно-палеогеографические критерии как инструмент корреляции континентальных и морских отложений миоцена платформенной Украины / В.Ю. Зосимович // Теоретичні та прикладні аспекти сучасної біостратиграфії фанерозою України. Київ. 2003. С. 87-89.

4. Кравченко О.A. Літостратиграфічне розчленування відкладів новопетрівської світи на площі Краснокутського родовища титано-цирконієвих руд / О.А. Кравченко //Тектоніка і стратиграфрія. 2015. Вип. 42. C. $90-96$.

5. Комлєв О.О. Історико-динамічні басейнові геоморфосистеми геоморфологічних фоормацій Українського щита: автореф. дис. ... д-ра географ. наук / О.О. Комлєв. Київ. 2005. 38 с.

6. Лаверов Н.П. Цифровое структурно-литологическое геолого-динамическое моделирование месторождений тяжелых минералов / Н.П. Лаверов, П.Ф. Гожик, Д.П. Хрущев и др. Киев; Москва: Интерсервис. 2014. 242 с.

7. Палиенко В.П. Новейшая геодинамика и её отражение в рельефе Украины / Палиенко В.П. К. : Наукова думка. 1992. $116 \mathrm{C.}$

8. Палієнко В.П. Природні географічні дослідження. Загальне геоморфологічне районування території України / В.П. Палієнко, М.Є. Барщевський, С.Ю. Бортник, Е.Т. Палієнко, Б.О. Вахрушев, Я.С. Кравчук, Р.М. Гнатюк, Ю.М. Зінько // Український географічнний журнал. 2004. № 1. С. 3-11. 
9. Патык-Кара Н.Г. Минералогия россыпей: типы россыпных провинций / Н.Г. Патык-Кара. М.: ИГЕМ РАН. 2008. $528 \mathrm{c}$.

10. Романов И.С. Геология и условия образования циркониево-титановых россыпей Днепровско-Донецкой впадины / И.С. Романов. Киев: Издательство «Наукова думка». 1976. 174 с.

11. Романов И.С. Закономерности размещения циркониево-титановых россыпей Днепровско-Донецкой впадины / И.С. Романов // Древние и погребенные россыпи СССР. Ч. 1: Сб. тр. Киев: Наук. Думка. 1977. $201 \mathrm{c}$.

12. Хрущев Д.П. Миоценовые титано-циркониевые россыпи Украинского щита и Днепровско-Донецкой впадины: стратиграфическое положение и палеогеографические условия / Д.П. Хрущев, В.Ю. Зосимович, Е.А. Кравченко [и др.]. // Материалы междунар. науч. конф. «Стратиграфия осадочних образований верхнего протерозоя и фанерозоя» (Киев, 23-26 сентября 2013 г.). K.: LAT\&K. 2013. C. 151-152.

13. Хрущов Д.П. Структурно-литологическое моделирование осадочных формаций / Д.П. Хрущов, М.С. Ковальчук, Е.А. Ремезова и др. Киев: Интерсервис. 2017. 352 с.

14. Цымбал С.Н. Минералогия титано-циркониевых россыпей Украины / С.Н. Цымбал, Ю.А. Полканов. Киев: Наук. Думка. 1975. 247 с.

15. Шило Н.А. Учение о россыпях. Владивосток: Дальнаука. 2002. 576 с.

\section{REFERENCES}

1. Zosimovich V.Yu. 1963. About Poltava suite on the right bank of the Middle Dnieper. Collection of studies SRS KSU. no. 1, p. 3-7. - in Russian

2. Zosimovich V.Yu., Savron E.B. 1978. Some questions of the nomenclature of the Poltava deposits. Geological Journal. vol. 38, no 6, p. 140-142. - in Russian

3. Zosimovich V.Yu. 2003. Event-paleogeographic criteria as an instrument of correlation of continental and marine deposits of Miocene platform of Ukraine. Theoretical and practical aspects of modern biostratigraphy of Phasnerozoic of Ukraine - Kyiv, p. 87-89. - in Russian

4. Kravchenko 0. 2015. Lithostratigraphic corelation of sediment of novopetrivska suite of Krasnokutsk titaniumzirconium placer deposit. Tectonica and stratigraphy. iss. 42, p. 90-96. - in Ukrainian

5. Komliev 0.0. 2005. Historical-geodynamic basin geomorphosystems of the geomorphosystem's formations of Ukrainian shield: author's abstract diss. for obtaining sciences. degree doc. geogr. sciences: special 11.00.04 "Geomorphology and paleogeography" - Kyiv, 38 p. - in Ukrainian

6. Laverov N.P., Gozhik P.F., Khrushchov D.P., Lalomov A.V., Lobasov A.P., Chizhova I.A., Kovalchuk M.S., Remezova E.A., Chefranov R.M., Bochneva A.A., Vasylenko S.P., Kravchenko E.A., Svivalneva T.V., Kroshko Yu.V. 2014. Digital structural-lithological geological and dynamical modelling of heavy minerals deposits. Interservis - Kiev, Moscow, 242 p. - in Russian

7. Palienko V.P. 1992. Newest geodynamics and its reflection in the relief of Ukraine - Kiev: Naukova Dumka, 116 p. - in Russian

8. Palienko V.P., Barshchevsky M.Ye., Bortnyk N.Yu. and etc. 2004. Natural geographic research. General geomorphological zoning of the territory of Ukraine. Ukrainian geographic journal. no. 1, p. 3-11. - in Ukrainian

9. Patyk-Kara N.G. 2008. Minerageny of placers: types of placer bearing provinces. IGEM PAN, Moscow, 528 p. in Russian

10. Romanov I.S. 1976. Geology and formation conditions of zirconium-titanium placers Dnieper-Donets depression. Naukova Dumka, Kiev, 174 p. - in Russian

11. Romanov I.S. 1977. Regularity of distribution of zirconium-titanium placers in Dnieper-Donets depression. Ancient and buried deposits of the USSR. Part 2: Proceedings. Naukova Dumka, Kiev, 201 p. - in Russian

12. Khrushchev D.P., Zosymovych V.Yu., Kravchenko O.A. 2013. Miocene titanium-zirconium placer of Ukrainian shield and the Dnieper-Donets depression: stratigraphic position, lithostratigraphy and paleogeography. Materialos of the international scientific conference "Stratigraphy of sedimentary formations of the upper Proterozoic and Phanerozoic. 23-26.09.2013 Kyiv. p. 151-152. - in Russian

13. Khrushchev D.P, Kovalchuk M.S., Remezova E.A., Lalomov A.V., Tsymbal S.M., Bosevskaya L.P., Lobasov A.P., Ganzha E.A., Dudchenko Yu.V., Kroshko Yu.V. 2017. Structural-lithological modeling of sedimentary formarions. - Kiev: Pub.Interservise, p. 352- in Russian

14. Tsymbal S.N., Polkanov Yu.A. 1975. Mineralogy of titanium-zirconium placers of Ukraine. Naukova Dumka, Kyiv, 247 p. - in Russian 
15. Shilo N.A. 2002. Teaching on placers deposits: The placer forming ore associations and generation theory, $2 n d$ ed., recasted and supplemented. Dalnauka, Vladivostok, 576 p. - in Russian

\section{O.A. Ganzha \\ CONDITION OF THE PLACEMENT OF THE FORMATION IN KRASNOKUTSK DEPOSIT AREA}

Basing upon paleorekonstruktions of Subperethetys evolution Middle-Novopetrivka phase, main condition of placers forming (tectonic, hydrodinamic, geomorphological and sedimentation) have been elaborated for Kharkiv-Sumy placers zone. The local scheme of placers forming has been founded for Krasnokutsk titanium-zyrconium deposit. This scheme is based upon the concept of placer forming material provision mainly by river by means of placer forming area directly neigh-boring to delta in the frames of two facial zones-coastal and marine shallow (shelf). The provision of placer forming matherial by lateral coastal streams and underlying sedimentation is also considered. Basing upon placers forming mechanism a set of criterions of placers prognosis in zonal scale has been developed: stratigraphic (the relation to Middle-Novopetrivka subsuite); facial (the foundation of two facial zones with pertinent ores characteristics), lithofacial (lithological types of sands), hidrodinamic (the availability of pertinent hydrodinamic conditions), paleotransportation (the presence of delta), paleogeomorphological and phases-sedimentation (the connection with sequence cycles of basin evolution with pertinent conditions of sedimentation).

Key words: mechanism of placer forming, titanium-zirconium placers, Krasnokutsk deposit, Middle-Novopetrivka subsuite, Miocene.

\section{Е.А. Ганжа \\ УСЛОВИЯ РОССЫПЕОБРАЗОВАНИЯ ТЕРРИТОРИИ КРАСНОКУТСКОГО МЕСТОРОЖДЕНИЯ}

На основе палеореконструкций средненовопетровского этапа развития Субпаратетиса определены основные условия россыпеобразования Харьковско-Сумской рассыпной зоны - тектонические, гидродинамические, геоморфологические и структурно-седиментационные. Предложено локальную схему россыпеобразования для площади Краснокутского месторождения, основанную на концепции поставки россыпеобразующего материала (РОМ) преимущественно речной артерией с образованием области россыпеобразования в непосредственном приближении к дельте в пределах двух фациальных зон - прибрежного мелководья и морского мелководья. Учитываются также поступления РОМ за счет латерального движения вдольбереговыми течениями и перемыва подстилающих и латерально прилегающих толщ. На основе представленного механизма россыпеобразования разработаны критерии прогнозирования россыпей в зональном масштабе: стратиграфический (приурочивание россыпей к средненовопетровской подсвите), фациальный (выделение двух россыпевмещающих зон с соответствующими характеристиками оруденения), гидродинамический, литофрациальный, палеотранспортный, палеогеоморфологический и этапноседиментационный (связь с сэквенсными цыклами эволюции бассейна с соответствующими условиями седиментации).

Ключевые слова: условия россыпеобразования, Краснокутское месторождение, титано-циркониевые россыпи, средненовопетровская подсвита, миоцен.

Інститут геологічних наук НАН України, м. Київ

Ганжа Олена Анатоліївна

E-mail: oag2909@gmail.com

Стаття надійшла: 16.10 .2017 